\title{
Examination of the Relation between Strategic Leadership Expectations and Organizational Justice: A Research on Health Sector
}

\author{
Ayhan Yalçınsoy \\ $\mathrm{PhD}$, Dicle University, Department of Business Administration, Turkey \\ E-mail: ayhanyalcinsoy@gmail.com \\ Cenk Aksoy \\ $\mathrm{PhD}$, Dicle University, Department of Aviation Management, Turkey \\ E-mail: cenkaksoy10@gmail.com
}

Received: Oct. 30, 2017 Accepted: Nov. 21, $2017 \quad$ Online published: Nov. 22, 2017

doi:10.5296/ijhrs.v8i1.12080 URL: https://doi.org/10.5296/ijhrs.v8i1.12080

\begin{abstract}
The aim of this study is to examine the relationship between strategic leadership and organizational justice within the healthcare sector. In the context of the study, the introduced model was tested by a questionnaire instrument with 41 items excluding demographic variables. A total of 320 completed questionnaires were used for analysis. Correlation, regression, $\mathrm{T}$ test and Anova analyzes were applied to the research data that obtained by the questionnaire. The study focused on the employees of hospitals in the Diyarbakir province of Turkey. The results suggest that there is a very strong positive linear relationship between strategic leadership and organizational justice variables. The result of the study is consistent with the results of previous research. Also, some disparities were observed among the demographic variables of the study.
\end{abstract}

Keywords: strategic leadership, organizational justice, health sector, leadership, organizational behaviour

\section{Introduction}

We may say that one of the most important contemporary issues regarding workplace management is the perception of trust that the workers have for the entity in which they are employed and the quality of relationships with the management. This issue has a profound effect on the performance of workers and therefore on the efficiency of the entity. Trust 
placed in a service provider is extremely important whether it comes from clients or workers. This kind of workplace environment may be established only by ensuring that the executives think long-term to secure and protect justice throughout the organization.

Justice is a value that is extremely desirable in social organizations, and a sense of justice is important for high quality business relationships (Erdoğan and Liden, 2006:3). One may not speak of various concepts such as tranquility, happiness, trust, respect and performance when there is no justice. Individuals deal with justice because it affects their economic gains the most, and they become a part of reputable groups, if they act fairly (Cropanzano et al., 2001:172).

In organizations, it is up to the top management to secure justice. It is the management-level executives, perceived as strategic leaders in recent years, who are responsible for securing justice in their organizations. If the workers have a perception that justice is secured in the organization, then workers remain happy and peaceful where they are employed even in challenging situations such as low salary levels or difficult work conditions.

When one examines the literature, it may be observed that there are few studies on organizational justice and strategic leadership. Research done on the subject is related to sub-levels of organizational justice and types of strategic leadership, and are assessed differently. We did not come across any study that directly examines the correlation between organizational justice and strategic leadership.

Research can be done in order to reveal the correlation between strategic leadership and organizational justice. Therefore, the primary question that emerges is: "Is there any correlation between strategic leadership and the perception of workers regarding organizational justice?". It is envisaged that the present research shall contribute to the studies that are made in this field since it assesses strategic leadership from various perspectives.

\section{Literature Review}

\subsection{Organizational Justice}

The concept of organizational justice is based on the equality theory initially revealed and developed by Adams (1965). According to Adams (1965), individuals compare their positions with various references continuously and uninterruptedly with others who have the same position as them (Özdevecioğlu, 2004). Individuals may surmise that there is an equality or inequality as a result of the comparisons they make. An individual who surmises that he/she is subjected to an inequality develops an attitude and behaviours against such inequality (Baş and Şentürk, 2011; Şahin and Taşkaya, 2010). These behaviours that are directed towards eliminating any inequality may be exhibited towards other individuals and also towards the related organization (Altıntaş, 2006:21).

Organizational justice includes implementation, making sovereign the encouragement of a fair and moral structure within the organization (İşcan and Sayın, 2010; Gül and İnce, 2014). According to Taşkıran (2011), the perception of organizational justice is focused on how 
much an organization perceives any behaviour to be fair rather than how fairly an individual is treated in reality (Sökmen, et al, 2013:46). Likewise, it ensures that the individuals in any organization make a judgement on how fairly they are treated. Accordingly, organizational justice is the perception that workers constitute in their world of thought in relation with the practices in the organization (Basim, et al 2011:176).

In other words, organizational justice may be defined as the method of organizing wages, rewards, penalties and promotions in an organization, methods of making such decisions, or methods of communicating such decisions to the workers as well as the perceptions formed by those workers (İçerli, 2010:69).

In current literature, organizational justice is assessed on the basis of three dimensions: distributional justice, procedural justice and interactional justice (Nadiri and Tanova, 2010:34; Pelit and Bozdoğan, 2014:39; Judge and Colquitt, 2004; Şahin and Taşkaya, 2010; Tutar, 2007; Yavuz, 2010; Polat and Celep, 2008; Bayramlık, et al. 2015; Olkkonen and Lipponen, 2006). Sub-levels that are revealed in relation with organizational justice are also referred to as distributional justice, procedural justice and interactional justice (Yıldırım, 2010). Relative sub-levels shall be referred to as above in the following sections of the study.

Distributional justice is included in equality theory. According to this theory, the reward of efforts made by individuals in any organization must match the level of such efforts (if it is equal, then in the form of a fee etc.) (İşcan and Naktiyok, 2004:187). Distributional justice considers sharing gains according to the principle of equality (Colquitt, 2001:386; Fox and Miles, 2001:294). According to this principle, individuals who are at the same level from any relative perspective, must be treated similarly, and individuals who are different must be treated in the ratio of the difference between those involved (İşcan and Sayın, 2010:196).

According to Greenberg (1990), distributional justice covers the perception that workers are treated fairly in terms of the rewards and incentives they receive in return of their efforts (Ang, et al., 2003:563). In this context, distributional justice is focused on various outputs, such as wage increases, performance assessments, rewards and penalties, etc. (Tutar 2007:99). The principle of distributional justice is that individuals must believe that they receive a fair share of distributed sources (Özdevecioğlu 2003; Iş1k et al 2012; Blakely et al., 2005).

Executives who implement distributional justice distribute rewards and penalties equally based on performance. However, it does not mean that everybody shall receive the same or equal level of rewards or penalties (İșcan and Sayın, 2010:196).

Procedural justice may be defined as the fairness level of the methods, procedures and policies that are used in the determination and measurement of various components, such as wage, promotion, financial opportunities, working conditions and performance assessment, etc. (Işık, et al., 2012; Fox and Miles, 2001; Johnson et al., 2006; K1lıçlar, 2011). In other words, procedural justice refers to the implementation of various organizational procedures equally among workmen, such as refraining from making excessive or deficient payment, participation in decisions and providing information on the results, etc. (İşcan and Sayın, 2010:197). Procedural justice promotes having a say in the process of decision-making or 
labelling outputs on the basis of equality process criteria, such as consistency, fairness, accuracy, representation, certainty and ethics, etc. (Colquitt, 2001:386).

Interactional justice level is a term used by Bies and Moag (1986) for the first time, and it is based on a study made in relation with the determination of interpersonal expectations during recruitment procedures. Interactional justice emphasizes the justice perception that occurs during any communication made between workers and executives who act as sources of justice. According to this level of organizational justice, it is essential that the communication process between the source of justice and the receiver is held within the framework of courtesy, respect and honesty (Colquitt, 2001; Iş1k et al, 2012; Johnson ,et al., 2006), i.e. interactional justice is relative to the level of candidness, sensitivity and respect that the management exhibits in its behaviours towards subordinates (Kaplan and Öğüt, 2012:3).

Folger and Bies (1989) defined interactional justice as managerial liabilities that are directed towards securing justice during implementation of decision-making procedures in organizations (Arslantaş and Pekdemir, 2007:267).

Interactional justice is related to the human aspect of organizational practices (Gül and İnce, 2014:131; K1lıçlar, 2011:25), i.e. that the things executives say to the individuals and the manner in which such things are said during a decision-making process (İşcan and Sayın, 2010:197) may affect the justice perception of workers. From this point of view, a justice perception is constituted according to the attitudes and behaviours that superiors exhibit during implementation of procedures (İyigün, 2012; Özdevecioğlu, 2003). In brief, we may say that distributional justice is related to workers, that procedural justice is related to the system, and that interactional justice is bi-directional (Johnson, et al., 2006:178).

Research done on organizational justice indicates that the concerns regarding justice affect the attitudes and behaviours of workers (Judge and Colquit, 2004:395). In this context, it is determined that the workers, who believe that they are treated fairly, shall exhibit behaviours that are to the benefit of the organization (Bayramlık, et al., 2015:161). Also, Pfeffer and Langton (1993) determined in the study they made that negative reactions towards low wage, organizational policies and organizational procedures are uttered less, if workers believe that the decision-making process is fair (İşcan ve Sayın 2010:196).

Workers exhibit positive attitudes and behaviours when they receive fair treatment, and they may exhibit negative behaviours when they perceive an unfair situation (İyigün, 2012:51). Workers who are of the opinion that they are subjected to an unequal treatment may withdraw themselves from work. Such a situation may cause performance loss, absence, leave of employment, abnormal behaviours and a decrease in the organizational citizenship behaviour of the workers (Blakely, et al., 2005; Özer and Urtekin, 2007).

\subsection{Strategic Leadership}

Although there are lots of studies available on leadership in related literature, leadership is still left as a concept that is not quite explained (Uğurluoğlu ve Çelik, 2009:122). Hersey and Blanchard (1969) define leadership as a behavioural pattern that leaders exhibit while at work (Alam, et al., 2014:83). In another definition, leadership is a process where a person affects 
and directs the activities of others in order to achieve certain personal or group objectives, and this process is mainly based on the capability of one person to affect others (Koçel, 2014:668).

Strategic leadership is the ability to form the future by envisaging it, to form a necessary strategic management mentality for such purposes, to authorize other executives and workers in that direction, to direct the same towards innovative and creative objectives in the direction of the corporate vision, and to ensure rapid strategic change, if necessary, in a complex global environment (Altıntaş, 2007).

Hitt, et al. (2001) defines strategic leadership as "having the ability to see and design the future, and to authorize others in order to perpetuate flexibility and to make strategic change, if necessary" (Sütçü, 2008:55). Ireland and Hitt (2005) define strategic leadership as the skills of seeing the future, creating a vision, ensuring flexibility, thinking strategically and the ability to work with others in order to initiate changes that may create a realisable future for strategic leadership and organization (Ŭgurlu and Çelik, 2009:126).

Strategic leaders focus on people who undertake any liability for the organization, and they do not only include the executives at the top of the organization, but also members of the top management team (Boal ve Hooijberg, 2001:516).

Strategic leaders are people who are placed in various departments within an entity in order to assist while achieving vision and mission objectives by using strategic management processes. Successful strategic leaders commit themselves to providing assistance without considering their positions in the entity during the formation of a value for all of the common groups of the entity (Volberda, et al., 2011:31).

In the scale referred to as "Strategic Leadership Scale" in the research and developed by Duursema (2013), Strategic Leadership is assessed under 4 sub-levels as below; Customer Orientation, Operational Efficiency, Business Development and Organizational Creativity (Duursema, 2013). To define,

Customer Orientation is assessed as establishing an environment of trust with both clients and partners.

Operational Efficiency is defined as preparation of detailed plans on how to achieve a critical duty.

Business Development is defined as making studies in the direction of business development by raising awareness in the clients on other goods and services provided by the entity.

Organizational Creativity is defined as suggesting new ideas that may convince the clients of the entity.

\subsection{Correlation between Strategic Leadership and Organizational Justice}

Although there are studies in the literature that are carried out directly on strategic leadership and organizational justice, there is no study that assesses the correlation between the two. The study that gets closest to this subject is the study made by Gül and Ince (2014), which 
examines the correlation between the sub-levels of ethical leadership and sub-levels of organizational justice. In this study, researchers revealed that the communicative and decision-making sub-levels of ethical leadership are correlated with procedural justice perceptions, and that the interactional justice sub-level of workers are correlated with procedural justice perceptions.

Arslantaş and Pekdemir (2007) assessed the correlation between transformational leadership, organizational citizenship behaviour and organizational justice in their study. Researchers concluded in their studies that transformational leadership makes an impact on the organizational citizenship behaviour of interpersonal justice thanks to the levels of charisma/giving inspiration and levels of interest on a personal level, and that the charisma/giving inspiration level and mental encouragement level of transformational leadership makes an impact on justice.

Asgari, et al. (2008) emphasized in their study that there is a positive and direct correlation between transformational leadership behaviours and organizational justice, between organizational citizenship behaviours and the leader-member relationship, and between perceived organizational support and trust as a tool.

Organizational justice perception refers to the perceptions of workers on how fairly they are treated in the workplace (Bayramlık, et al. 2015; Johnson, et al., 2006). In this context, following the determination of Erdoğan and Liden (2006:1) is important: "A leader is a critical source of the justice perception in a business environment, and therefore, justice perception is related with the attitudes and behaviours directed towards leaders".

We may develop the following hypotheses in relation to the subject based on the explanations above as they relate to the concepts of organizational justice perception and strategic leadership:

$\mathrm{H}_{1}$ : "There is a positive correlation between the strategic leadership expectation and organizational justice perception of workers".

$\mathrm{H}_{2}$ : "There is a positive linear correlation between strategic leadership and sub-levels of organizational justice."

$\mathrm{H}_{3}$ : "Strategic leadership has a great affect on organizational justice perception."

As a result of the hypotheses formed by a focused study of literature we may develop the following research model, which shows the correlation between the concepts of organizational justice perception and strategic leadership (Figure 1). 


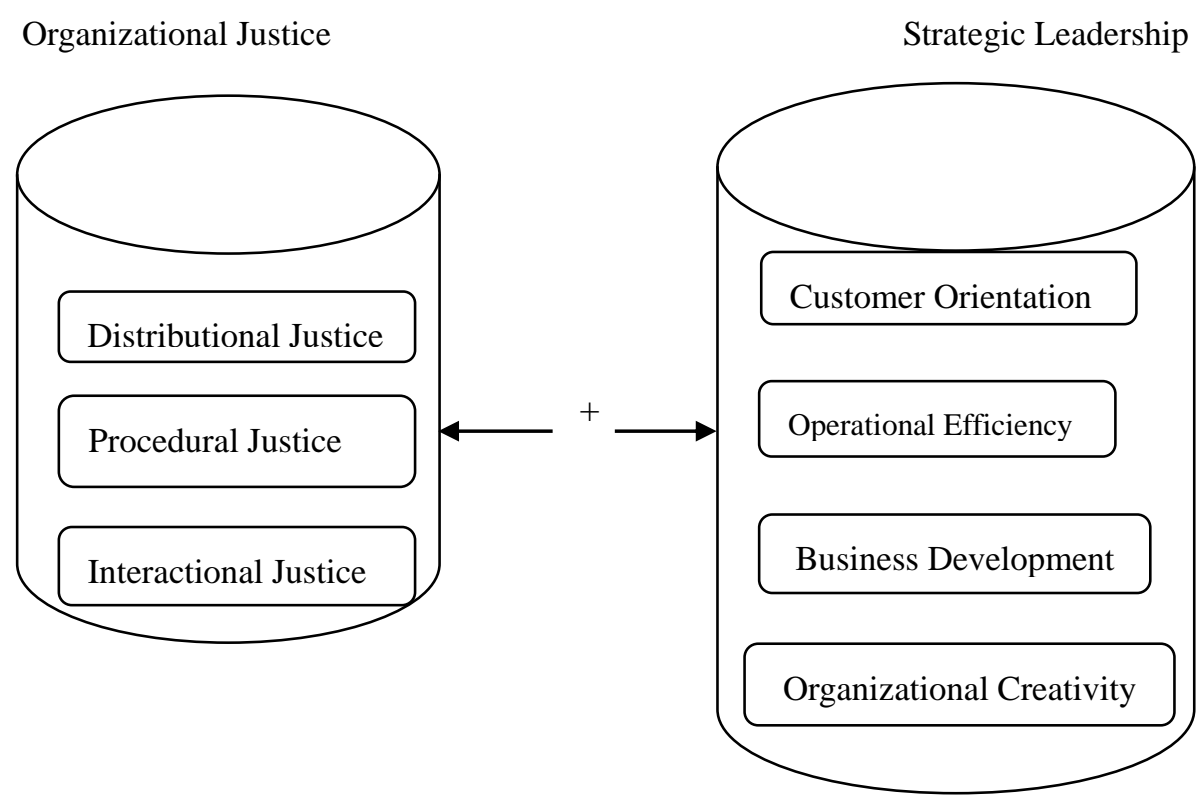

Figure 1. Research Model

\section{Methodology of Research}

Research Population and Sample: A questionnaire comprising 41 questions is used to test the hypotheses and the model, except for demographical variables. These surveys are distributed to healthcare personnel at any level who are employed in public or private hospitals that operate in Diyarbakır; 320 questionnaires are used for analysis.

Data Collection Tools: During collection of data, in addition to a demographic information form, two different scaled surveys are applied for the purpose of determining organizational justice perception and strategic leadership levels.

a) Demographic Information Form: This questionnaire, which aims to collect demographic information in relation to corporate employees, includes various features, such as age, gender, education status, marital status, work experience, title, etc.

b) Organizational Justice Perception Scale: "Organizational Justice Perception Scale" is measured by using the organizational justice perception scale developed by Colquitt (2001) and is adapted by Özmen, Arbak and Özer (2007); it comprises 20 articles. According to the reliability analysis made by Özmen, Arbak and Özer (2007), Cronbach Alpha values are found to be 0.94 for distributional justice perception level, 0.86 for procedural justice perception level, and 0.88 for interactional justice perception level. In the reliability analysis of the questionnaire (within the scope of the research), Cronbach Alpha values are found to be 0.95 for distributional justice perception level, 0.89 for procedural justice perception level, and 0.96 for interactional justice perception level. As a result of the analysis of all values obtained from the Organizational Justice Perception Scale, Cronbach Alpha values are found to be 0.97 . Distribution is normal since $\mathrm{p}>0.5$ in the Kolmogrov Simornov test.

c) Strategic Leadership Scale: The Strategic Leadership Scale developed by Duursema (2013), which includes 20 questions, is translated to Turkish and 1 question is added 
subsequently. Duursema assesses Strategic Leadership under 4 sub-levels: Customer Orientation, Operational Efficiency, and Business Development and Organizational Creativity.

According to the reliability analysis made by Duursema, Cronbach Alpha values are found to be 0.82 for Customer Orientation, 0.89 for Operational Efficiency, 0.88 for Business Development and 0.79 for Organizational Creativity. In the reliability analysis of the questionnaire (within the scope of the research), Cronbach Alpha values are found to be .91 for Customer Orientation, 0.92 for Operational Efficiency, 0.92 for Business Development and 0.92 for Organizational Creativity. As a result of the analysis performed on all of the values obtained from Strategic Leadership, Cronbach Alpha values are found to be 0.97 . Distribution is normal since $\mathrm{p}>0.5$ in Kolmogrov Simornov test.

Analysis of Data: SPSS 18.0 statistics program is used during the assessment of data. Also, correlation, regression, t-test and ANOVA analyses are used during comparison of variables. Assessment of the data is based on total points obtained by participants as a result of each answer they gave to a question. In this research, the statistical significance level is considered to be $\mathrm{p}<0,5$.

\section{Results}

Correlation and regression analyses were used to test the research hypotheses. Information about the people who participated in the research are presented in the following tables. As it is seen in this table, 302 people from among the employees working in health businesses participated in the research.

Table 1. Demographic variables

\begin{tabular}{|c|c|c|c|}
\hline Variables & Percentage (\%) & Variables & Percentage (\%) \\
\hline \multicolumn{2}{|l|}{ Gender } & \multicolumn{2}{|l|}{ Marital Status } \\
\hline Male & 60,9 & Married & 68,6 \\
\hline Female & 39,1 & Single & 31,4 \\
\hline \multicolumn{2}{|l|}{ Title } & \multicolumn{2}{|c|}{ Work Experience } \\
\hline Doctor & 21,2 & $1-5$ years & 31,2 \\
\hline Nurse & 21,9 & $6-10$ years & 28,4 \\
\hline Officer & 24,1 & $11-15$ years & 20 \\
\hline Technician & 14,7 & $16-20$ years & 11,6 \\
\hline Other & 18,1 & 21 and above & 8,8 \\
\hline \multicolumn{2}{|l|}{ Age } & \multicolumn{2}{|l|}{ Education } \\
\hline $21-24$ & 10,6 & Primary school & 7,5 \\
\hline $25-29$ & 23,8 & High school & 35,6 \\
\hline $30-34$ & 25,9 & University & 53,4 \\
\hline $35-39$ & 20 & Master & 2,8 \\
\hline $40-44$ & 14,4 & Phd & 0,6 \\
\hline 45 and above & 5,3 & Total & 100 \\
\hline
\end{tabular}

n: 320

Research was performed between January and April, 2015. As it may be observed in Table 1, out of 320 workers, the total number of participants who participated to the research, 125 $(39,1 \%)$ of the participants were female and 195 of the participants $(60,9 \%)$ were male. 34 
$(10,6 \%)$ of the participants were aged between 21-24, $76(23,8 \%)$ participants were aged between 25-29, $83(25,9 \%)$ participants were aged between 30-34, 64 (20\%) participants were aged between 35-39, 46 (14,4\%) participants were aged between 40-44, and $17(5,3 \%)$ participants were aged 45 and above. $24(7,5 \%)$ of the participants were primary school graduates, $114(35,6 \%)$ were high school graduates, $171(53,4 \%)$ were university graduates, 9 $(2,8 \%)$ had a masters degree and $2(0,6 \%)$ had a Phd. $219(68,4 \%)$ of the participants were married and $101(31,6 \%)$ were single. Regarding work experience, $100(31,2 \%)$ of the participants had work experience of 1-5 years, $91(28,4 \%)$ had work experience of 6-10 years, $64(20 \%)$ had work experience of 11-15 years, $37(11,6 \%)$ had work experience of 16-20 years and $28(8,8 \%)$ had work experience of 21 years and above. Regarding the titles of healthcare personnel who participated in the research from various levels, $68(21,2 \%)$ were doctors, $70(21,9 \%)$ were nurses, $77(24,1 \%)$ were office staff, $47(14,7 \%)$ were technicians and $58(18,1 \%)$ were employed in various other positions.

As it may be seen in Table 2 below, there is a very strong positive linear correlation between strategic leadership and organizational justice $(\mathrm{p}<0,001)$. Therefore, the research hypothesis is accepted.

Table 2. Correlation between Strategic Leadership and Organizational Justice

\begin{tabular}{|c|c|c|c|}
\hline & & 1 & 2 \\
\hline 1. Strategic Leadership & \multirow{2}{*}{$\begin{array}{l}\text { Spherman } \\
\text { Correlation } \\
\text { Coefficient }\end{array}$} & 1 &, $748^{* *}$ \\
\hline 2. Organizational Justice & & & 1 \\
\hline
\end{tabular}

**Correlation is significant at the 0.01 level (2-tailed).

As it may be seen in Table 3 below, there is also a very strong positive linear correlation between sub-levels of strategic leadership and organizational justice $(p<0.001)$. Therefore, the research hypothesis is accepted.

Table 3. Correlation between Sub-levels of Strategic Leadership and Organizational Justice

\begin{tabular}{|c|c|c|c|c|c|c|c|c|}
\hline & & 1 & 2 & 3 & 4 & 5 & 6 & 7 \\
\hline $\begin{array}{ll}1 . & \text { Distributional } \\
\text { Justice } & \\
\end{array}$ & \multirow{7}{*}{$\begin{array}{l}\text { Spherman } \\
\text { Correlation } \\
\text { Coefficient }\end{array}$} & \multirow[t]{7}{*}{1} &, 835 &, $793^{* *}$ & $\begin{array}{l}, 657 \\
* *\end{array}$ &, $581 * *$ & $493 * *$ & ,548* \\
\hline 2. Procedural Justice & & & \multirow[t]{6}{*}{1} &, $866 * *$ &, $660 * *$ &, $644 * *$ &, $551 * *$ & $\begin{array}{l}, 582 * \\
*\end{array}$ \\
\hline 3. Interactional Justice & & & & \multirow[t]{5}{*}{1} & $695 * *$ &, $714 * *$ &, $602 * *$ & $\begin{array}{c}, 630 * \\
*\end{array}$ \\
\hline $\begin{array}{ll}4 . & \text { Customer } \\
\text { Orientation }\end{array}$ & & & & & \multirow[t]{4}{*}{1} &, $701 * *$ &, $642 * *$ & $\begin{array}{c}, 691 * \\
*\end{array}$ \\
\hline $\begin{array}{l}5 . \quad \text { Operational } \\
\text { Efficiency }\end{array}$ & & & & & & \multirow[t]{3}{*}{1} &, $685 * *$ & $\begin{array}{l}, 721 * \\
*\end{array}$ \\
\hline $\begin{array}{l}6 . \quad \text { Business } \\
\text { Development }\end{array}$ & & & & & & & \multirow[t]{2}{*}{1} & $\begin{array}{l}, 801 * \\
*\end{array}$ \\
\hline $\begin{array}{l}\text { 7. Organizational } \\
\text { Creativity }\end{array}$ & & & & & & & & 1 \\
\hline
\end{tabular}

**Correlation is significant at the 0.01 level (2-tailed). 
As it may be seen in Table 4 below, the total variation of the organizational justice variable related to strategic leadership is determined to be $56 \%$. Therefore, the $\mathrm{H}_{3}$ hypothesis is also accepted.

Table 4. Strategic Leadership and Organizational Justice Regression Analysis

\begin{tabular}{c|ccccccc}
\hline $\begin{array}{c}\text { Dependent } \\
\text { Variable }\end{array}$ & $\mathbf{R}^{\mathbf{2}}$ & $\begin{array}{c}\text { Independent } \\
\text { Variable }\end{array}$ & $\mathbf{B}$ & Beta & $\mathbf{t}$ & $\mathbf{p}$ & VIF \\
\hline $\begin{array}{c}\text { Strategic } \\
\text { Leadership }\end{array}$ & 0,56 & $\begin{array}{c}\text { Organizational } \\
\text { Justice }\end{array}$ & 30.98 & 0.746 & 14.59 & 0,000 & 1,48 \\
\hline
\end{tabular}

There is no auto correlation in this model since Durbin Watson: $1.48<\mathbf{d}=\mathbf{1 . 9 5}<4$.

In addition to the aforementioned analyses, anova and average analysis results are found according to certain demographic variables:

- Significant differences are determined among age groups in terms of customer orientation, operational efficiency and organizational creativity, which are all sub-levels of Strategic Leadership. Such differences are found in the groups aged from 20 to 35 (F:4.91, p<0,005; $F: 3.54, p<0,005 ; F: 2.56, p<0,05)$.

- Significant differences are determined within the scope of work experience in terms of operational justice and interactional justice, which are both sub-levels of Organizational Justice. Such differences are found among workers with work experience of 21 years and above (F:4.15, p<0,005; F:3.52, p<0,005).

- According to the answers given by the workers who participated in the research, on the strategic leadership scale, $\overline{\mathrm{x}}: 3,38$ and organizational justice perception $\overline{\mathrm{x}}: 3,10$.

\section{Conclusion}

The research is done in order to determine the existence of a correlation between strategic leadership and organizational justice in terms of workers employed in the healthcare sector. As a result of the research, a positive and very strong linear correlation is determined between strategic leadership and organizational justice. Obtained results are consistent with the studies done previously on the correlation between various types and sub-levels of leadership and organizational justice (Gül and İnce, 2014; Arslantaş and Pekdemir, 2007; Asgari, et al., 2008).

According to the research results, we may say that as the strategic leadership expectations of the workers in healthcare increase, their organizational justice perceptions also increase in a positive direction. If we consider that the service rendered by healthcare workers is crucial, the importance of the issue shall be understood more clearly. Therefore, senior executives employed in the healthcare sector must re-assess the performance of workers in terms of both strategic leadership and the efficiency of the organization because of the strong correlation between these two concepts.

Research reveals that organizational justice perceptions affect strategic leadership in the healthcare sector at a critical level. This situation may be interpreted as follows: workers employed in healthcare may work more effectively and efficiently in a fair work environment 
in terms of the sub-levels of such concepts, i.e. customer orientation, doing business, and creative behaviours. Convincingly, satisfying and new ideas provided in healthcare services are required continuously by any part of the society and affect the competition level positively. Also, the development of the sense of justice among healthcare employees, who are known for their high speciality level, provide positive results in terms of both healthcare organizations and their workers.

As we look at research conducted within the healthcare sector, we observe how important are both the leadership behaviours and the workers' expectations of organizational justice (Tutar, 2007; Şahin and Taşkaya, 2010; Kaplan and Öğüt, 2012). "Organizational justice causes the legality of the organization to be perceived, and executives play the key role in terms of achieving organizational objectives" (Moorman, 1991:852).

According to another result obtained in connection with the research, significant differences are determined among age groups in terms of customer orientation, operational efficiency and organizational creativity, which are all sub-levels of strategic leadership. Such differences are found in groups aged from 20 to 35. This situation may be interpreted as follows: the strategic leadership expectations of younger workers are higher in comparison to other age groups. Also, executives may benefit from young workers more effectively when they exhibit strategic leadership behaviours.

In terms of operational justice and interactional justice, which are both sub-levels of organizational justice, significant differences are found in the research within the scope of work experience. Differences are found among workers having work experience of 21 years or more. Procedural justice is defined as the fairness level of the methods, procedures and policies that are used in determination and measurement of various components, such as wage, promotion, financial opportunities, working conditions and performance assessment. Interactional justice is related to the level of candidness, sensitivity, and the respect that the management exhibits in its behaviours towards subordinates. In this context, we find that the justice expectation of those with more work experience is equally high. In other words, experienced workers expect their managers to be more sensitive, more candid and more relaxed in their behaviours toward them.

The correlation between strategic leadership levels and organizational justice used in the present research for the first time makes the research unique in comparison to prior research done on leadership and organizational justice. Also, it is envisaged that the very strong correlation levels determined in the present research shall shed light on subsequent research.

Since the research is limited to the hospitals that operate in the Diyarbakır province, and since limited numbers of questionnaires are used, such factors may be referred to as basic limitations. Also, it is another limitation that workers who provide service in the healthcare sector may not have answered questions in the survey as carefully as possible because of their intense workload. 


\section{References}

Adams, J. S. (1965). Inequity in Social Exchange. In L. Berkowitz (Ed.), Advances in Experimental Social Psychology, 2, 267-299. New York: Academic Press. https://doi.org/10.1016/S0065-2601(08)60108-2

Alam, K., Ali, A., Ali, N., \& Zaman, G. (2014). Organizational Justice, Task Enjoyment, Leadership style and Organizational Culture as Strategies for Reduction of Social Loafing. Abasyn University Journal of Social Sciences, 7(1), 77-99.

Altıntaş, F. Ç. (2006). Bireysel Değerlerin Örgütsel Adalet ve Sonuçları İlişkisinde Yönlendirici Etkisi: Akademik Personel Üzerinde Bir Analiz. Dokuz Eylül Üniversitesi İşletme Fakültesi Dergisi, 7(2), 19-40.

Altıntaş, N. (2007). Stratejik Liderlik ve Yetenek Yönetimi. http://arsiv.ntv.com.tr/news/249410.asp (20.05.2015).

Ang S., Dyne, L. V., \& Begley, T. M. (2003). The Employment Relationships of Foreign Workers Versus Local Employees: A Field Study of Organizational Justice, Job Satisfaction, Performance, and OCB. Journal of Organizational Behavior, 24, 561-583. https://doi.org/10.1002/job.202

Arslantaş, C. C., \& Pekdemir, I. (2007). Dönüşümcü Liderlik, Örgütsel Vatandaşlık Davranışı Ve Örgütsel Adalet Arasındaki İlişkileri Belirlemeye Yönelik Görgül Bir Araştırma, Anadolu Üniversitesi Sosyal Bilimler Dergisi, 1, 261-286.

Asgari, A., Silong, A. D., Ahmad, A., \& Abu, S. B. (2008). The Relationship Between Transformational Leadership Behaviors, Leader-Member Exchange and Organizational Citizenship Behavior. European Journal of Social Sciences, 6(4), 140-151.

Aykan, E. (2004). Kayseri'de Faaliyet Gösteren Girişimcilerin Liderlik Özellikleri. Erciyes Üniversitesi Sosyal Bilimler Enstitüsü Dergisi, 17(2), 213-224.

Baş, G., \& Şentürk, C. (2011). İlköğretim Okulu Öğretmenlerinin Örgütsel Adalet, Örgütsel Vatandaşlık ve Örgütsel Güven Algıları. Kuram ve Uygulamada Eğitim Yönetimi Dergisi, 17(1), 29-62.

Bayramlık, H., Çetin, Ş., \& Yurdakul, A. T. (2015). İnsan Kaynakları Yönetimi Uygulamalarının Örgüte Duyulan Güvene Etkisi: Örgütsel Adaletin Aracılık Rolü. Işs,Güç Endüstri Ilişkileri ve Insan Kaynaklarl Dergisi, 17(2), 156-173. https://doi.org/10.4026/1303-2860.2015.0282.x

Bies, R. J., \& Moag, J. F. (1986). Interactional Justice: Communication Criteria of Fairness. Research on Negotiations in Organizations, 1, 43-55.

Blakely, G. L., Andrews, M. C., \& Moorman, R. H. (2005). The Moderating Effects Of Equity Sensitivity on the Relationship Between Organizational Justice and Organizational Citizenship Behaviors. Journal of Business and Psychology, 20(2), 259-273. https://doi.org/10.1007/s10869-005-8263-3 
Boal, K. B., \& Hooijberg, R. (2001). Strategic Leadership Research: Moving on. The Leadership Quarterly, 11(4), 515-549. https://doi.org/10.1016/S1048-9843(00)00057-6

Colquitt, J. A. (2001). On the Dimensionality of Organizational Justice: a Construct Validation of a Measure. Journal of Applied Psychology, 86(3), 386-400. http://dx.doi.org/10.1037/0021-9010.86.3.386

Cropanzano, R., Byrne, Z. S., Bobocel, D. R., \& Rupp, D. E. (2001). Moral Virtues, Fairness Heuristics, Social Entities, and Other Denizens of Organizational Justice. Journal of Vocational Behavior, 58(2), 164-209. https://doi.org/10.1006/jvbe.2001.1791

Duursema, H. (2013). Strategic Leadership: Moving Beyond The Leader-Follower Dyad. Rotterdam: Erasmus University Rotterdam. https://repub.eur.nl/pub/39129/EPS2013279ORG9789058923240.pdf

Erdoğan, B., \& Liden, L. R. (2006). Collectivism as a Moderator of Responses to Organizational Justice: Implications For Leader-Member Exchange and Ingratiation. Journal of Organizational Behavior, 27, 1-17. https://doi.org/10.1002/job.365

Fox, S., Spector, P. E., \& Miles, D. (2001). Counterproductive Work Behavior (Cwb) In Response to Job Stressors and Organizational Justice: Some Mediator and Moderator Tests For Autonomy and Emotions. Journal of Vocational Behavior, 59(3), 291-309. https://doi.org/10.1006/jvbe.2001.1803

Greenberg, J. (1990). Organizational Justice: Yesterday, Today, and Tomorrow. Journal of Management, 16, 399-432. https://doi.org/10.1177/014920639001600208

Gül, H., \& İnce, M. (2014). Etik Liderlik ve Örgütsel Adalet Arasındaki İlişkiler Üzerine Bir Araştırma. Niğde Üniversitesi İ̈BF Dergisi, 7(2), 127-150.

Hersey, P., \& Blanchard, K. H. (1969). Life Cycle Theory of Leadership. Training \& Development Journal, 23(5).

Hitt, M., Duane, I. R., Michael, C. S., \& Donald, L. S. (2001). Guest Editors' Introduction to The Special Issue, Strategic Entrepreneurship: Entrepreneurial Strategies for Wealth Creation, Strategic Management Journal, 22, 479-491. https://doi.org/10.1002/smj.196

İçerli, L. (2010). Örgütsel Adalet: Kuramsal Bir Yaklaşım. Girişimcilik ve Kalkınma Dergisi, 5(1), 67-92.

Ireland, R. D., \& Hitt, A. M. (2005). Achieving and Maintaining Strategic Competitiveness in the 21st century: The Role of Strategic Leadership. Academy of Management Executive, 19, 63-78. https://doi.org/10.5465/AME.2005.19417908

İşcan, Ö. F., \& Naktiyok, A. (2004). İşgörenların Örgütsel Bağdaşımlarının Belirleyicileri Olarak Örgütsel Bağl1lık ve Örgütsel Adalet Algıları. Ankara Üniversitesi SBF Dergisi, 59(1), 181-201.

İşcan, Ö. F., \& Sayın, U. (2010). Örgütsel Adalet, İş Tatmini ve Örgütsel Güven Arasındaki İlişki. Atatürk Üniversitesi İktisadi ve İdari Bilimler Dergisi, 24(4), 195-216. 
Işık, O., Uğurluoğlu, Ö., \& Akbolat, M. (2012). Sağlık Kuruluşlarında Örgütsel Adalet Algılarının Örgütsel Bağlılığa Etkisi. Doğuş Üniversitesi Dergisi, 13(2), 254 - 265

İyigün, N. Ö. (2012). Örgütsel Adalet: Kuramsal Bir Yaklaşım. Ístanbul Ticaret Üniversitesi Sosyal Bilimler Dergisi, 11(21), 49-64.

Johnson, R. E., Selenta, C., \& Lord, R. G. (2006). When Organizational Justice and the Self-Concept Meet: Consequences for the Organization and its Members. Organizational Behavior and Human Decision Processes, 99(2), 175-201. https://doi.org/10.1016/j.obhdp.2005.07.005

Judge, T. A., \& Colquitt, J. A. (2004). Organizational Justice And Stress: The Mediating Role of Work-Family Conflict. Journal of Applied Psychology, 89(3), 395-404. https://doi.org/10.1037/0021-9010.89.3.395

Kaplan, M., \& Ögüt, A. (2012). Alg1lanan Örgütsel Adalet İle Sanal Kaytarma Arasındaki İlişkinin Analizi: Hastane Çalışanları Örneği. Dokuz Eylül Üniversitesi İşletme Fakültesi Dergisi, 13(1), 1-13

Kiliçlar, A. (2011). Yöneticiye Duyulan Güven İle Örgütsel Adalet İlişkisinin Öğretmenler Açısından İncelenmesi. İşletme Araştırmaları Dergisi, 3(3), 23-36.

Koçel, T. (2014). İşletme yöneticiliği. (15 Baskı). İstanbul: Beta Yayınları.

Meydan, C. H., Basım, H. N., \& Çetin, F. (2011). Örgütsel Adalet Algısı ve Örgütsel Bağlılığın Tükenmişlik Üzerine Etkisi: Türk Kamu Sektöründe Bir Araştırma. Türk Dünyası Sosyal Bilimler Dergisi, 57, 175-200.

Moorman, R. H. (1991). Relationship Between Organizational Justice and Organizational Citizenship Behaviors: Do Fairness Perceptions Influence Employee Citizenship? Journal of Applied Psychology, 76(6), 845-855. https://doi.org/10.1016/j.sbspro.2012.06.905

Nadiri, H., \& Tanova, C. (2010). An Investigation of The Role Of Justice in Turnover Intentions, Job Satisfaction, and Organizational Citizenship Behavior in Hospitality Industry. International Journal of Hospitality Management, 29(1), 33-41. https://doi.org/10.1016/j.ijhm.2009.05.001

Olkkonen, M. E., \& Lipponen, J. (2006). Relationships Between Organizational Justice, Identification With Organization and Work Unit, and Group-Related Outcomes. Organizational Behavior and Human Decision Processes, 100(2), 202-215. https://doi.org/10.1016/j.obhdp.2005.08.007

Özdevecioğlu, M. (2003). Algılanan Örgütsel Adaletin Bireylerarası Saldırgan Davranışlar Üzerindeki Etkilerinin Belirlenmesine Yönelik Bir Araştırma. Erciyes Üniversitesi İktisadi ve İdari Bilimler Dergisi, 21(21), 77-96.

Özdevicioğlu, M. (2004). Duygusal Olaylar Teorisi Çerçevesinde Pozitif ve Negatif Duygusallığın Alınan Örgütsel Adalet Üzerindeki Etkilerini Belirlemeye Yönelik Bir Araştırma. Ankara Üniversitesi SBF Dergisi, 59(03), 181-202. 


\section{$\triangle$ Macrothink}

International Journal of Human Resource Studies ISSN 2162-3058

Özer, P. S., \& Urtekin, G. E. (2007). Örgütsel Adalet Algısı Boyutları Ve İş Doyumu İlişsisi Üzerine Bir Araştırma. Erciyes Üniversitesi İktisadi ve İdari Bilimler Dergisi, 28(28), 107-125.

Özmen, Ö. N. T., Arbak, Y., \& Özer, P. S. (2007). Adalete Verilen Değerin Adalet Algılar1 Üzerindeki Etkisinin Sorgulanmasına İlişkin Bir Araştırma. Ege Academic Review, 7(1), 17-33.

Pelit, E., \& Bozdoğan, İ. (2014). İşgörenların Örgütsel Adalet Algılamalarının Tükenmişlik Düzeyleri Üzerindeki Etkisi: Kemer'deki Beş Yıldızlı Otel İşletmelerinde Bir Uygulama. Journal Of Business Research Turk, 6(2), 37-66. https://doi.org/10.20491/isader.2014215953

Pfeffer, J., \& Langton, N. (1993). The Effect of Wage Dispersion on Satisfaction, Productivity, and Working Collaboratively: Evidence from College and University Faculty, Administrative Science Quarterly, 38, 382-407. https://doi.org/10.2307/2393373

Polat, S., \& Celep, C. (2008). Ortaöğretim Öğretmenlerinin Örgütsel Adalet, Örgütsel Güven, Örgütsel Vatandaşlık Davranışlarına İlişkin Algıları. Kuram ve Uygulamada Eğitim Yönetimi Dergisi, 14(54), 307-331.

Şahin, B., \& Taşkaya, S. (2010). Sağlık Çalışanlarının Örgütsel Adalet Algılarını Etkileyen Faktörlerin Yapısal Eşitlik Modeli İle İncelenmesi. Hacettepe Sağlık İdaresi Dergisi, 13(2) 86-114.

Sökmen, A., Bilsel, M. A., \& Erbil, C. (2013). Örgütsel Adaletin İşgören Motivasyonu Ve Performansı Üzerindeki Etkisi: Bankacılık Sektöründe Bir Araştırma. İktisadi ve İdari Bilimler Fakültesi Dergisi, 15(1), 43-62.

Sütçü, O. (2008). Stratejik Liderlik, Kahramanmaraş Sütçü İmam Üniversitesi Sosyal Bilimler Enstitüsü, Yayımlanmamış Yüksek Lisans Projesi, Kahramanmaraş.

Tanrıöğen, Z. M., Baştürk, R., \& Başer, M. U. (2014). İlköğretim Okulu Müdürlerinin Algılarına Göre Dört Liderlik Çerçevesi Modeli Kullanımı. Ĕgitim ve Öğretim Araştırmaları Dergisi, 3(1), 348-358.

Taşkıran, E. (2011). Liderlik ve örgütsel sessizlik arasındaki etkileşim-örgütsel adaletin rolü. İstanbul: Beta.

Teyfur, M., Beytekin, F. O., \& Yalçınkaya, M. (2013). İlköğretim Okul Yöneticilerinin Etik Liderlik Özellikleri İle Okullardaki Örgütsel Güven Düzeyinin İncelenmesi (İzmir İl Örneği). Dicle Üniversitesi Ziya Gökalp Eğitim Fakültesi Dergisi, 21, 84-106.

Tutar, H. (2007). Erzurum'da Devlet Ve Özel Hastanelerde İşgören Sağlık Personelinin İşlem Adaleti, İş Tatmini Ve Duygusal Bağlılık Durumlarının İncelenmesi. Süleyman Demirel Üniversitesi İktisadi ve İdari Bilimler Fakültesi Dergisi, 12(3), 97-120.

Uğurluoğlu, Ö., \& Çelik, Y. (2009). Örgütlerde Stratejik Liderlik Ve Özellikleri. Hacettepe Să̆lık Iddaresi Dergisi, 12(2), 121-156.

Volberda, H. W., Morgan, R. E., Reinmoeller, P., Hitt, M. A., Ireland, R. D., \& Hoskisson, R. 


\section{Macrothink}

International Journal of Human Resource Studies

ISSN 2162-3058 2018, Vol. 8, No. 1

E. (2011). Strategic Management: Competitiveness and Globalization (Concepts \& Cases). Cengage Learning. http://www.cengagebrain.co.uk/content/9781408048856.pdf (15.05.2015).

Yavuz, E. (2010). Kamu ve Özel Sektör Çalışanlarının Örgütsel Adalet Algılamaları Üzerine Bir Karşılaştırma Çalışması. Doğuş Üniversitesi Dergisi, 11(2), 302-312.

Yıldırım, A. (2010). Etik Liderlik ve Örgütsel Adalet İlişkisi Üzerine Bir Uygulama, Karamanoğlu Mehmet bey Üniversitesi, Sosyal Bilimler Enstitüsü, Yayımlanmamış Yüksek Lisans Tezi, Karaman.

\section{Copyright Disclaimer}

Copyright for this article is retained by the author(s), with first publication rights granted to the journal.

This is an open-access article distributed under the terms and conditions of the Creative Commons Attribution license (http://creativecommons.org/licenses/by/4.0/). 